\title{
CORRIGENDA
}

\section{The Utilization of Nitriles and Amides by Nocardia rhodochrous}

\author{
By PAULINE A. COLLINS AND CHRISTOPHER J. KNOWLES
}

Journal of General Microbiology (1983), 129, 711-718

p. 715, Table 3:

for 'Enzyme activity [mmol $\left.\mathrm{min}^{-1}(\mathrm{mg} \text { protein) })^{-1}\right]^{\prime}$ read 'Enzyme activity [ $\mu \mathrm{mol} \mathrm{min}^{-1}(\mathrm{mg}$ protein $\left.)^{-1}\right]^{\prime}$

p. 715 , text:

line 7 , for ' $64 \mu \mathrm{mol}$ ammonia formed $\mathrm{min}^{-1}(\mathrm{mg} \mathrm{dry} \mathrm{wt})^{-1}$ ' $r e a d$ ' $64 \mathrm{nmol}$ ammonia formed $\mathrm{min}^{-1}$ (mg dry wt) $)^{-1}$,

line 11 , for ' $28 \mu \mathrm{mol}$ ammonia formed $\mathrm{min}^{-1}$ (mg protein) ${ }^{-1}$ ' read ' $28 \mathrm{nmol}$ ammonia formed $\min ^{-1}$ (mg protein) $)^{-1}$

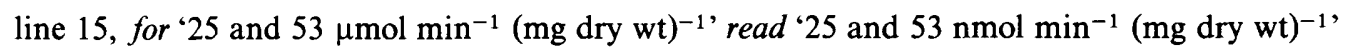

\section{Methanogenic Degradation of Sodium Benzoate in Profundal Sediments from a Small Eutrophic Lake}

By ROBERT SLEAT AND JOHN P. ROBINSON

Journal of General Microbiology (1983), 129, 141-152

p. 144, Table 1, footnote:

The term ' $\mathrm{CO}$ ' in the equation should read ' $\mathrm{CO}_{2}$ '.

p. 151, last line of text:

for 'converted into labelled gases' read 'not converted into labelled gases'. 